\title{
Reconhecimento, Identidade e Trabalho Sujo na PMDF
}

\author{
Márcio Júlio da Silva Mattos \\ Orientador: Analía Laura Soria Batista \\ Dissertação de Mestrado \\ Data da defesa: 19.04.2012
}

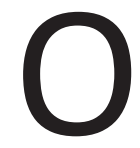

presente trabalho discorre sobre a construção identitária dos policiais militares do Distrito Federal diante da estigmatização da atividade policial como trabalho sujo. Em detalhe, a maneira como esses profissionais estabelecem suas relações sociais guarda estreito vínculo com o cenário cultural em torno de seu trabalho. Nesse sentido, o desprestígio associado à estigmatização da profissão constitui fator inequívoco de estruturação da identidade policial militar. Para tanto, utiliza-se o debate do reconhecimento social como categoria referencial à teoria social, em que a ação social é marcada por uma base motivacional afetiva. A construção identitária, dessa forma, referese à autocompreensão positiva de si mesmo, cujo contraste são as situações vivenciadas como experiências de desrespeito, as quais negam reconhecimento ao sujeito. Nesse sentido, o trabalho policial é percebido dentre as ocupações que se inserem marginalmente na divisão moral do trabalho, trazendo consigo o sentido simbólico do sujo.

Dois grupos de sujeitos compõem a pesquisa: os noviços e os demissionários. Os primeiros são representados pelos policiais militares que ingressaram na instituição em 2010. Já os demissionários são constituídos pelos profissionais que voluntariamente deixaram a carreira desde 2000 até 2011. Dessa forma, analisaram-se as suas percepções, reações e sentimentos acerca do reconhecimento social da atividade policial. Ainda mais, buscaram-se problematizar as distinções sobre a estigmatização do trabalho policial, as reações emocionais que caracterizam as experiências de desrespeito vividas, bem como as autorrelações positivas acerca de seus modos distintos de vida, ou seja, seu habitus. Diante das análises, assinalaram-se as expectativas em torno do ingresso, bem como as motivações para a demissão no contexto da PMDF. Foram discutidas as distinções e racionalizações que marcam as interações internas, em que as construções dignificantes, como as categorias dos vibradores e dos operacionais, disputam com as funções estigmatizadas, como os encagaçados e os administrativos. Além disso, a discussão da socialização na polícia militar 
permitiu compreender os efeitos da estigmatização sobre a forma como o trabalho policial é percebido e, por conseguinte, desempenhado na PMDF. Nesse sentido, insere-se a noção de violência expressiva na interpretação de distinções diante dos relatos apresentados.

Palavras-chave: Polícia Militar, Reconhecimento Social, Identidade e Trabalho Sujo. 